\title{
Analysis on the Problems of Students' Party Construction in Zhuhai Special Economic Zone and Its Countermeasures
}

\author{
Zhiwei Liu \\ Zhuhai School of Jilin University \\ Zhuhai, China
}

\author{
Junliang Kong \\ Zhuhai School of Jilin University \\ Zhuhai, China
}

\begin{abstract}
At present, there is no local undergraduate university in Zhuhai. Relying on the advantages of running schools in north, the northern universities built the independent school in Zhuhai and established a university zone. The development of independent school has become a major part of developing universities and colleges in Zhuhai. In view of its inherent dependence, the independent school has all the disparity in teaching resource, human force and base installation compared with the mother of the independent school. This essay will briefly analyze the problems the Zhuhai independent school will confront during its students' party construction work and expect to come up with some corresponding solutions.
\end{abstract}

Keywords - the special economic zone; the independent school; party construction work; solutions of problem

\section{THE INDEPENDENT SCHOOL IN THE SPECIAL ECONOMIC ZONE}

Early in August 1980, Zhuhai had become the special economic zone. The SEZ began to develop following 30 years of China's reform and opening up. The economic development also requires the talents education accordingly. As a significant part in developing China's higher education in the future, the independent school fused well with Zhuhai thanks to its special nature. Currently, Zhuhai does not own its local undergraduate universities, but a total of three independent schools were located in that place. They include Zhuhai school of Jilin University (opened in 2004), Zhuhai School of Beijing Normal University (opened in 2001) and Zhuhai School of Beijing Institute of Technology (opened in 2004). The three independent schools were applied for establishment by their mother universities and supported by the government og Zhuhai county.

After carrying out the related teaching and management activities, the corresponding primary party construction work was taken on gradually in the independent schools. Many management mechanisms were brought in from their mother universities, from theoretical study, the construction of party branches, and the activities of party branches to the development of party members. In a great degree, those methods weren't revised and improved, which, however, cannot satisfy the current developing requirements of Zhuhai Independent School in the Special Economic Zone. After all, the certain disparity between the development of SEC and other northern area exists. More rapidly the SEC develops, more frequent the cultural communication is, and more strict demands the school needs to manage the education and advance with the times for the party construction work. Therefore, the work body of most independent schools is, actually, a defect in the work of party construction. Even the defect was enlarged in the SEC because of its regional feature. To say the least, on the one hand, the dependence of the independent schools over its mother universities can benefit the development of schools as a new staff. However, on the other hand, this dependence also restricts its own development on creation and innovation in some degree. Moreover as the top priority task in the independent schools, the party construction work confronts with many difficulties. Therefore, only when the defect that dependence of the independent schools over their mother universities is foreseen, better countermeasures can be discovered.

\section{SOME PROBLEMS DURING THE STUDENTS' PARTY CONSTRUCTION WORK}

\section{A. Party Construction Team Is Weak.}

The independent schools value little of the party construction work due to its nature of public running and being sponsored by private enterprises. With the constant enlargement of schools' enrollments, the party construction team can hardly deal with the outbreak of students required to be the party member. However, most of the primary party workers take part-time in it, including a post is taken in by students, which makes the party work difficult to concentrate on. In addition, the given fond also greatly limits the party construction work of the independent schools because of the special of the independent schools.

\section{B. The Motivations of Students to Join the Party Are Diversified and Complicated.}

With the establishment and perfection of the social market economy, the philosophy, values and behaviors habits have experienced tremendous changes. Some students having weak communism beliefs join the party neither to purely serve the people, nor to struggle for a life-long time in order to achieve the cause of communism. That is inconsistent with the party's purpose that serving the people heart and soul. 


\section{The Focus of Working Is Not Balanced}

The development of student party members is one of the core content of party construction work. However, deviation often occurs when schools develop their student party member. This deviation often expresses in two aspects: First, it is not distinct that whether the main emphasis is on the party construction of students or teachers. Student party member development is the basis stone and the top key of party construction work. Different from the staff party member, party construction work should carry out properly and on target. Second, before joining the party, much cultivation is given to the students, but after joining the party, less and less education can be received. It tends to formality the students' development that if the work only pay attention to the preparty education. Later the ignorance of education after joining the party will make party members lack of minds armed by ideological and political theory. In conclusion, the same attention should be paid in the education of both before and after joining the party.

\section{SUGGESTIONS AND COUNTERMEASURES FOR STRENGTHENING SCHOOLS' PARTY CONSTRUCTION}

\section{A. To Strengthen the Construction of Party Worker Teams and Improve Students' Abilities on Party Construction}

Combined the school characteristics with actual work, schools should take effective measures to strengthen the party's ideology, organization, style and system construction, also to select young teachers with high ideological and political quality and enthusiasm in student party construction work, so that to enable them to concentrate on student party construction work with enough energy and practice. In addition, certain financial supports is necessary in developing students' party construction.

\section{B. Based on the Spirits of Scientific Outlook on Development and Important Guiding Ideology of 18th National Congress of CPC, Schools Should Strengthen the Ideal Faith Education and Regular the Students' Motivation to Join the Party}

The motivation education of joining the party is a significant part of the education which schools organize for party activists. In order to correct the motivation of joining the party, schools should put the education of ideal and faith at first. Through all kinds of the party's basic theory knowledge teaching and party spirit education activities, beginning with improving and cultivating the party spirit of student party members, students should be armed by the powerful weapon of marxism-leninism, Mao Zedong's thought, Deng Xiaoping 'theory and "Three Represents" important thoughts. Schools should make sure students realize the party's advanced nature, and also to understand that as a contemporary college student, one's shoulder shall bear the responsibility and mission.

\section{To Set Up and Improve the Training and Inspection System of Student Party Activists}

Schools should build up the cultivators contact system. Since a student submits applications for joining the party, the correspondent party branch should arrange party members to contact and talk with the applicant. The cultivators should give the student affirmation and encouragement, and guide and educate him or her on the early period to specify a further plan for the student's improvement. In addition, the cultivators should grasp the student's thoughts, and help him or her analyze the current problems timely and accurately to encourage the student to overcome the deficiency in the thoughts. Moreover the cultivators should often the party activists' class to widely understand their situation and listen to the head teachers of youth league branch and other students' perspectives, by which partial and subjectivity of guidance can be avoided. The cultivators need to record the truth of performance, behavior, grades and ideological understanding of the party activists timely, so as to reflect their comprehensive conditions and be convenient to their further inspection.

\section{CONCLUSION}

With the rapid developing trend of the independent schools in recent years, the party construction work should follow up with the education closely under the relevant central spirits. However, on the whole, the thorough academic researches on the SEZ independent schools' party construction work are still too limited. At present, a more mature mode of work and practice being worthy of borrowed has not been formed, yet. Therefore, the social community should increase on the research of party construction work in colleges and universities, and provide theoretical supports for the independent schools' party construction. Also, schools should launch investigations and researching frequently and vigorously, for summarizing and promoting the advanced experience during the party construction work, so as to constantly improve the abilities of private universities on party constructing.

\section{REFERENCES}

[1] Zhao Guangnian, Ma Dingwei, and Wei Jian. Thinking on the Innovation of party Construction and ideological and political work in Independent Colleges[J]. Journal of Private Higher Education Research, 2008, (01).

[2] Ning Ting-ting. Thinking on the CPC Party Construction in Independent Colleges Chinese Education, 2010/03

[3] Yang Mengyu. Implement the Scientific Concept of Development and Improve Party Construction Work. Political Discussion, 2010/09

[4] Tang Zhengling. Problems existing in the independent college students' party construction in the new period and the countermeasures. Reform and Opening up, 2011/12 